\title{
GROWTH AND PHOSPHATE UPTAKE OF IMMOBILIZED ACINETOBACTER CELLS SUSPENDED IN ACTIVATED SLUDGE MIXED LIQUOR
}

\author{
N. Y. O. MUYIMA and T. E. CLOETE
}

\section{INTRODUCTION}

Enhanced biological phosphorus removal is an important alternative to chemical phosphorus precipitation. Although other bacteria have shown phosphate uptake abilities (Brodisch and Joyner, 1982), Acinetobacter has become the model organism in the biological process of phosphorus removal from activated sludge (AS) plants (Stephenson, 1987; Toerien et al., 1990). However, a lack of understanding of the mechanisms involved, mainly due to the lack of suitable techniques for studying these bacteria in situ prevails.

Immobilization of pure cultures of Acinetobacter could facilitate the in situ study of these organisms, to possibly explain the mechanism of phosphorus uptake by these bacteria. Immobilization of phosphate accumulating bacteria could also possibly provide an efficient phosphate removal process from wastewater compared to conventional suspended growth reactors (Gersberg and Allen, 1984). However, the behaviour of phosphorus accumulating bacterial cells (like Acinetobacter) in the immobilized state must be understood before any further development in this regard can take place.

Observations on immobilized cells indicated that these cells behave differently from cells free in solution (Mattiasson and Hahn-Hägerdal, 1982). Immobilization could affect microbial cell viability and/or growth (Doran and Bailey, 1986). Higher specific rates of substrate utilization for immobilized cells have been demonstrated (Navarro and Durand, 1977; Vijayalakshmi et al., 1979) while, conditions for optimal growth have been reported to differ from those for suspended cells (Doran and Bailey, 1986).

Although various immobilization matrices e.g. kappa-carrageenan, iota-carrageenan, polyacrylamide (Takata et al., 1977) have been used, combined factors such as the cost, the stability at low concentration of the cross-linker and the ease of formulation have resulted in alginate remaining the preferred material for immobilization studies (Poncelet et al., 1992).

The objectives of this study were therefore to assess the effects of immobilization on viability, leakage rate, growth and phosphate uptake ability of immobilized Acinetobacter cells suspended in AS mixed liquor using alginate as the immobilization matrix.

\section{MATERIALS AND METHODS}

Bacterial cultures used in this study

Cultures of Acinetobacter johnsonii strain 105 obtained from the Department of Microbiology and Plant Pathology, University of Pretoria and Acinetobacter calcocaeticus strain ATCC $23055^{\mathrm{T}}$ were used.

Inocula were prepared by incubation of an aliquot of the respective bacterial stock cultures in $100 \mathrm{ml}$ Biolab nutrient broth on an Edmund Bühler TH10 rotary shaker, 160rpm at $28 \mathrm{C}$ for $12 \mathrm{~h}$ and $72 \mathrm{~h}$.

\section{Culture medium for phosphorus removal studies}

Activated sludge mixed liquor was collected from the anaerobic tank of the Daspoort activated sludge plant at Pretoria. It was filtered on Whatman filter paper (ø $185 \mathrm{~mm})$ and enriched with $5 \mathrm{mg} / 1$ $\mathrm{CH}_{3} \mathrm{COONa}, 0.18 \mathrm{~g} / 1 \mathrm{KNO}_{3}$ and $0.5 \mathrm{~g} / 1 \mathrm{MgSO}_{4} \cdot 7 \mathrm{H}_{2} 0$, before autoclaving. The nutrient additions were adapted from Bosch and Cloete (1993).

\section{Immobilization technique}

Entrapment of bacteria within alginate beads was carried out using a modification of the method of Bashan (1986). 3\% and 3.5\% sodium alginate (BDH) solutions were used. $4 \mathrm{ml}$ of the $72 \mathrm{~h}$ bacterial culture (for viability and leakage studies) and $0.1 \mathrm{ml}$ of the $12 \mathrm{~h}$ bacterial culture (for growth study) respectively were mixed with $20 \mathrm{ml}$ sodium alginate at room temperature on a Heidolph MR2002 shaker at $600 \mathrm{rpm}$. The matrix and bacteria mixture was then added dropwise using a sterile $20 \mathrm{ml}$ syringe, $26 \mathrm{G}$ needle into $150 \mathrm{ml}$ of sterile $\mathrm{CaCl}_{2}$ solution $(1.1 \% \mathrm{~m} / \mathrm{v})$ at room temperature. Beads were immediately formed in the $\mathrm{CaCl}_{2}$ solution entrapping Acinetobacter cells. Beads maintained for an 
additional $1 \mathrm{~h}$ in the $\mathrm{CaCl}_{2}$ solution were then washed three times with sterile distilled water. $3 \%$ and $3.5 \%$ alginate beads entrapping a similar volume of sterile Biolab nutrient broth were used as controls.

Viability determination of the immobilized Acinetobacter cells

Approximately $15 \mathrm{~g}$ alginate beads containing entrapped Acinetobacter cells, were placed into $100 \mathrm{ml}$ sterile AS mixed liquor and incubated on a rotary shaker, $160 \mathrm{rpm}$ at $28 C$. Every hour, $0.1 \mathrm{~g}$ alginate beads were removed from the reaction vial and washed in sterile distilled water. To recover bacteria for viable counts, the beads were immersed in $1 \mathrm{ml}$ phosphate buffer $(1 \mathrm{M}, \mathrm{pH} 7)$ and dissolved by vigorous mixing on a Heidolph 54111 shaker for approx. $1 \mathrm{~min}$. Serial dilutions and viable cell counts were performed on Biolab nutrient agar plates incubated at $28 \mathrm{C}$ for $24 \mathrm{~h}$.

\section{Determination of leakage of immobilized Acinetobacter cells}

Every hour, simultaneously with immobilized cells viability monitoring, serial dilutions and viable cell counts were also performed using the AS mixed liquor to determine whether any bacteria cells had leaked out of the alginate beads into the AS mixed liquor.

\section{Growth of immobilized A cinetobaeter cells}

Immobilized Acinetobacter $(0.1 \mathrm{ml}-12 \mathrm{~h}$ culture $)$ cells were washed with sterile distilled water before determining the initial number of viable cells. Thereafter, $14.5 \mathrm{~g}$ beads were suspended in $100 \mathrm{ml}$ AS mixed liquor and incubated on a rotary shaker, $160 \mathrm{rpm}$ at $28 \mathrm{C} .0 .1 \mathrm{~g}$ beads were removed hourly from the mixed liquor and washed with sterile distilled water. Bacterial cells were recovered for colony counts. Alginate beads without bacteria were used as control.

\section{Growth of Acinetobacter free cells}

$0.5 \mathrm{ml}$ inoculum of free cells were inoculated into $100 \mathrm{ml}$ AS mixed liquor (this provided the same ratio as for immobilized cells) and the same cultural conditions, as for the immobilized cells were used. Viable cell counts were performed hourly on Biolab nutrient agar plates, incubated at $28 \mathrm{C}$ for $24 \mathrm{~h}$.

The growth rate $(R)$ - the number of generations per hour was determined using the following formula:

$$
R=\frac{n}{t}=\frac{2.303\left(\log _{10} N_{1}-\log _{10} N_{0}\right)}{\left(t_{1}-t_{0}\right)}
$$

where, $R$ means the growth rate, $n$ the number of generations, $N_{1}$ the total population at time one, and $N_{0}$ the number of bacteria at time zero.

\section{Phosphate uptake determinations}

Two replicates of $1 \mathrm{ml}$ AS mixed liquor each were removed hourly from the experimental vial and filtered through a Millex-GS $0.22 \mu \mathrm{m}$ filter unit to remove all cells. Phosphate determinations as orthophosphate were performed on the filtrate with the P(VM) 14842 test kit (Merck) using the Merck SQ118 photometer. Phosphate uptake (mg/1) and phosphate uptake per cell were calculated as follows:

$$
\begin{aligned}
& {[\mathrm{P} \text { uptake }(\mathrm{mg} / 1)]=[\mathrm{P} \text { uninoculated control }(\mathrm{mg} / 1)]-[\mathrm{P} \text { sample }(\mathrm{mg} / 1)]} \\
& {[\mathrm{P} \text { uptake/cell }]=[\mathrm{P} \text { uptake }(\mathrm{mg} / 1)] \div[\mathrm{cfu} / \mathrm{ml} \text { after incubation } \mathrm{x} 1000] .}
\end{aligned}
$$

\section{RESULTS AND DISCUSSION}

\section{The effect of alginate concentration on the viability of immobilized Acinetobacter strains}

Immobilized $A$. johnsonii and $A$. calcoaceticus cells remained viable over a $24 \mathrm{~h}$ monitoring period, although no growth occurred when $10^{7}-10^{8} \mathrm{cfu} / \mathrm{ml}$ of initial cell concentrations were used (Figs 1-4). Space, oxygen, water activity and nutrient transfer could be limiting growth factors at such high cell densities (Mattiasson and Hahn-Hägerdal, 1982) and these factors could contribute to the limited growth which occurred.

A. johnsonii showed a typical stationary growth phase pattern with slight fluctuations within viable cell numbers comparing between 3\% and 3.5\% alginate (Figs 1 and 3). Although, A. calcoaceticus remained in the stationary phase, it showed rather high fluctuations within viable cell numbers (Figs 2 and 4).

The biomass ratio (cfu/ml after $24 \mathrm{~h} \div \mathrm{cfu} / \mathrm{ml}$ initial density) of $A$. calcoaceticus was higher than that for A. johnsonii whilst 3.5\% alginate immobilized cells presented a higher biomass ratio compared to $3 \%$ alginate (Table 1). 3.5\% aginate therefore had a more pronounced stressed effect on the viability of both strains, than $3 \%$ whilst $A$. calcoaceticus was more affected than $A$. johnsonii 


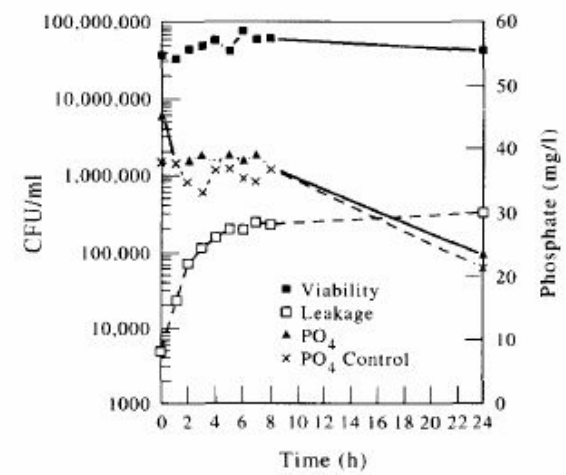

Fig. I. Viability, leakage and phosphate uptake relationship of immobilized $A$. johnsonii cells within $3 \%$ alginate beads suspended in AS mixed liquor.

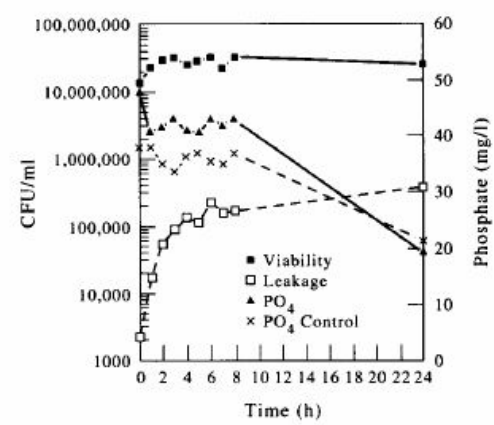

Fig. 2. Viability, leakage and phosphate uptake relationship of immobilized $A$. calcoaceticus cells within $3 \%$ alginate beads suspended in AS mixed liquor

The effect of immobilization on the viability of Acinetobacter cells was dependent, both on alginate concentration, the strain under consideration and the cell density.

\section{Leakage rate of immobilized Acinetobacter cells}

Both A. johnsonii and A. calcoaceticus leaked out of the 3\% and 3.5\% alginate beads (Figs 1-4). A slightly higher leakage rate was observed at 3\% than at 3.5\% alginate for both $\mathrm{A}$. johnsonii and $\mathrm{A}$. $\mathrm{Ca}$ coaceticus (Table 2).

A. johnsonii compared to A. calcoaceticus gave a higher leakage rate indicating that leakage rate might be dependent upon the concentration of alginate and the strain under consideration.

Both $A$. johnsonii and A. calcoaceticus leaked cells showed typical growth curves indicating the viability of leaked cells (Figs 1-4).

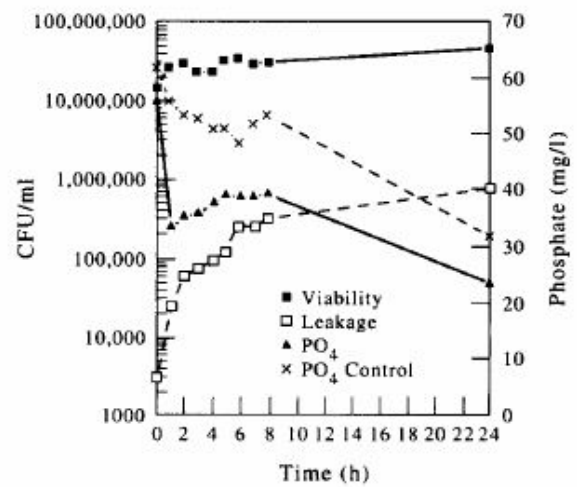

Fig. 3. Viability, leakage and phosphate uptake relationship of immobilized $A$. johnsonii cells within $3.5 \%$ alginate beads suspended in AS mixed liquor.

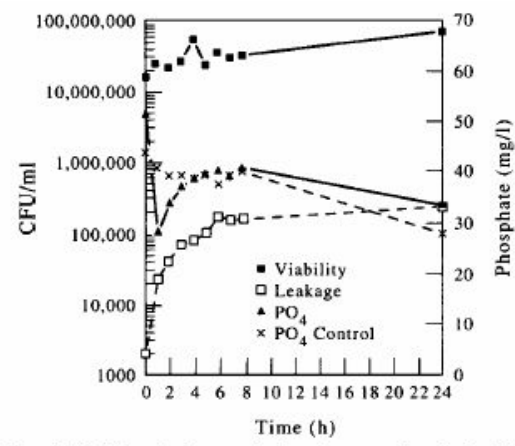

Fig. 4. Viability, leakage and phosphate uptake relationship of immobilized $A$. calcoaceticus cells within $3.5 \%$ alginate beads suspended in AS mixed liquor.

\section{Growth of immobilized and free Acinetobacter cells}

$12 \mathrm{~h}$ cultures of both immobilized and free A. johnsonii cells presented ascendent growth curves, requiring no time to adapt to their new environmental conditions (Fig. 5). Growth rates determined for immobilized and free $A$. johnsonii cells were 0.91 and 0.84 , respectively. Similar growth rates between immobilized and free cells were also reported by Dhulster et al. (1984). The stationary growth phase was reached after $9 \mathrm{~h}$ (Fig. 5).

A. calcoaceticus immobilized cell numbers declined after inoculation and started growing after $2 \mathrm{~h}$, while free cells started growing immediately. Immobilized A. calcoaceticus cells therefore did not adapt immediately to the new environmental conditions probably as a response to stress. Similar observations 
were reported by Shinmyo et al. (1982). Growth rates calculated for immobilized and free cells were 1.24 and 0.65 , respectively. The stationary growth phase was also reached after $9 \mathrm{~h}$ (Fig. 6). Increase in microbial cell numbers within gel matrices compared to free cells have been reported for Azospirilum brasilense and Saccharomyces carlsbergensis cells (Bashan, 1986). This was also observed in this study where immobilized $A$. johnsonii and A. calcoacelicus cells yielded more biomass after $24 \mathrm{~h}$ than free cells (Table 1).

Table 1. Biomass ratios of immobilized A. johnsonii and A. calcoaceticus cells within $3 \%$ and $3.5 \%$ alginate beads

\begin{tabular}{lcc}
\hline & \multicolumn{2}{c}{ Biomass ratios $\left(\mathrm{T}_{24} / \mathrm{T}_{0}\right)$} \\
\cline { 2 - 3 }$\%$ Alginate & A. johnsonii & A. calcoaceticus \\
\hline 3.0 & 1.1 & 2.0 \\
3.5 & 2.8 & 4.2 \\
\hline
\end{tabular}

Table 2. Leakage rate of immobilized A. johnsonii and A. calcoaceticus cells within $3 \%$ and $3.5 \%$ alginate beads

Leakage rate $(\mathrm{cfu} / \mathrm{ml})$

\begin{tabular}{lcc}
\cline { 2 - 3 }$\%$ Alginate & A. johnsonii & A. calcoaceticus \\
\hline 3.0 & $5.04 \times 10^{3}$ & $2.26 \times 10^{3}$ \\
3.5 & $3.17 \times 10^{3}$ & $1.19 \times 10^{3}$ \\
\hline
\end{tabular}

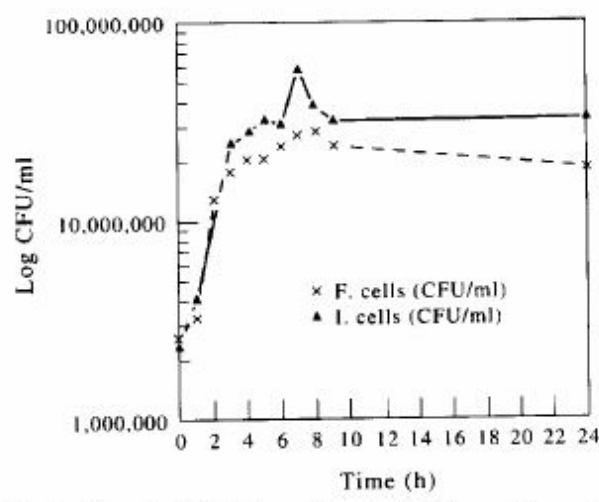

Fig. 5. Growth of $A$. johnsonii strain 105 free and immobilized cells suspended in AS mixed liquor.

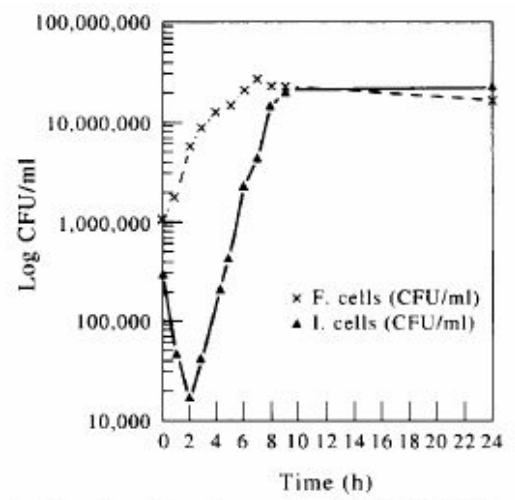

Fig. 6. Growth of A, calcoaceticus ATCC23055 ${ }^{\mathrm{T}}$ free and immobilized cells suspended in AS mixed liquor.

\section{Phosphate uptake by immobilized growing cell systems}

Phosphate in the figures and tables, indicates the rate of orthophosphate expressed as $\mathrm{mg}$ per litre (ppm) or per cell. Both A. johnsonii and A. calcoaceticus growing systems did not remove phosphate within the first hour of incubation. However, A. johnsonii showed phosphate uptake after $24 \mathrm{~h}$ of incubation (Table 3). A. calcoaceticus showed no phosphate uptake whilst growing. These results are in agreement with the findings by Harold (1963), Lawson and Tonhazy (1980), and Bosch (1992) who indicated that polyphosphate accumulation took place only when cells were not actively multiplying i.e. during lag and/or stationary growth stages.

Phosphate uptake by immobilized cells in the stationary phase

In order to keep cells in the stationary phase, cells harvested after $72 \mathrm{~h}$ were used as inocula. As control, 
$3 \%$ alginate beads without bacteria absorbed $1.1 \times 10^{-3} \mathrm{mg} \mathrm{P} / 1$ per $\mathrm{mg}$ of alginate. A. johnsonii and $A$. calcoaceticus immobilized ( $3 \%$ alginate) cells removed $2.4 \times 10^{-10}$ and $2.9 \times 10^{-10} \mathrm{mg} \mathrm{P} /$ cell, respectively after $1 \mathrm{~h}$ of incubation (Figs 1 and 2, Table 4). After $24 \mathrm{~h}$, A. calcoaceticus immobilized cells removed more phosphate per cell than $A$. johnsonii cells $\left(4.5 \times 10^{-10}\right.$ compared to $\left.1.3 \times 10^{-10} \mathrm{mg} / \mathrm{cell}\right)$. $A$. johnsonii cells removed more phosphate after $1 \mathrm{~h}$ compared to $24 \mathrm{~h}\left(2.4 \times 10^{-10}\right.$ compared to $1.3 \times 10^{-10}$ $\mathrm{mg} / \mathrm{cell}$ ) while on the contrary, A. calcoaceticus removed more phosphate per cell after $24 \mathrm{~h}$, compared to $1 \mathrm{~h}\left(4.5 \times 10^{-10}\right.$ compared to $2.9 \times 10^{-10} \mathrm{mg} /$ cell $)$. Between $1 \mathrm{~h}$ and $24 \mathrm{~h}$, A. johnsonii showed a decrease in phosphate uptake per cell, while A. calcoaceticus phosphate uptake per cell gradually increased. From $2 \mathrm{~h}$ to $8 \mathrm{~h}$, phosphate release was sporadically observed for both strains.

Table 3. Phosphate uptake of immobilized Acinetobacter growing cells within 3\% alginate beads

\begin{tabular}{|c|c|c|c|c|c|}
\hline \multirow[b]{2}{*}{ Strain } & \multirow[b]{2}{*}{ Time (h) } & \multicolumn{2}{|c|}{$\mathrm{cfu} / \mathrm{ml}$} & \multicolumn{2}{|c|}{ Phosphate } \\
\hline & & Before incub. & After incub. & $\mathrm{mg} / \mathrm{l}$ & $\mathrm{mg} /$ cell \\
\hline $\begin{array}{l}\text { johnsonii } \\
105\end{array}$ & $\begin{array}{l}\text { After } 1 \mathrm{~h} \\
\text { From } 8-24 \mathrm{~h} \\
\text { After } 24 \mathrm{~h}\end{array}$ & $\begin{array}{l}9.45 \times 10^{5} \\
3.20 \times 10^{7}\end{array}$ & $\begin{array}{l}2.57 \times 10^{6} \\
2.95 \times 10^{7} \\
2.95 \times 10^{7}\end{array}$ & $\begin{array}{l}-3 \\
0.5 \\
1\end{array}$ & $\begin{array}{l}-\overline{-} \\
1.7 \times 10^{-11} \\
3.3 \times 10^{-11}\end{array}$ \\
\hline $\begin{array}{l}\text { calcoaceticus } \\
{\text { ATCC } 23055^{\mathrm{T}}}\end{array}$ & $\begin{array}{l}\text { After } 1 \mathrm{~h} \\
\text { From } 8-24 \mathrm{~h} \\
24 \mathrm{~h}\end{array}$ & $\begin{array}{l}9.40 \times 10^{4} \\
7.35 \times 10^{5}\end{array}$ & $\begin{array}{l}2.40 \times 10^{4} \\
4.50 \times 10^{7} \\
4.50 \times 10^{7}\end{array}$ & $\begin{array}{l}-2 \\
0 \\
-0.5\end{array}$ & $\overline{0}$ \\
\hline
\end{tabular}

Note: - means negative uptake and should be interpreted as phosphate release.

Table 4. Phosphate uptake of immobolized Acinetobacter non-growing cells within $3 \%$ alginate beads

\begin{tabular}{llllll}
\hline & & \multicolumn{2}{c}{ cfu/ml } & \multicolumn{2}{c}{ Phosphate } \\
\cline { 3 - 6 } Strain & Time (h) & Before incub. & After incub. & $\mathrm{mg} / 1$ & $\mathrm{mg} / \mathrm{cell}$ \\
\hline \multirow{2}{*}{$\begin{array}{l}\text { johnsonii } \\
\text { 105 }\end{array}$} & & & & & \\
& After 1 h & $3.77 \times 10^{7}$ & $3.39 \times 10^{7}$ & 8.12 & $2.4 \times 10^{-10}$ \\
& From 8 - 24 h & $6.01 \times 10^{7}$ & $4.28 \times 10^{7}$ & -1.62 & - \\
& After 24 h & & $4.28 \times 10^{7}$ & 5.75 & $1.3 \times 10^{-10}$ \\
calcoaceticus $_{\text {ATCC23055 }}^{\mathrm{T}}$ & & & & & \\
& After 1 h & $1.28 \times 10^{7}$ & $2.19 \times 10^{7}$ & 6.38 & $2.9 \times 10^{-10}$ \\
& From 8 - 24 h & $3.24 \times 10^{7}$ & $2.50 \times 10^{7}$ & 8.25 & $3.3 \times 10^{-10}$ \\
& 24 h & & $2.50 \times 10^{7}$ & 11.25 & $4.5 \times 10^{-10}$ \\
\hline
\end{tabular}

Note: - means negative uptake and should be interpreted as phosphate release.

Table 5. Phosphate uptake of immobilised Acinetobacter non-growing cells within $3.5 \%$ alginate beads

\begin{tabular}{llllll}
\hline & & \multicolumn{2}{c}{ cfu/ml } & \multicolumn{2}{c}{ Phosphate } \\
\cline { 3 - 6 } Strain & \multicolumn{1}{c}{ Time (h) } & Before incub. & After incub. & $\mathrm{mg} / 1$ & $\mathrm{mg} / \mathrm{cell}$ \\
\hline johnsonii & & & & \\
105 & After 1 h & $1.55 \times 10^{7}$ & $2.79 \times 10^{7}$ & 16.5 & $5.9 \times 10^{-10}$ \\
& From 8 - 24 h & $3.04 \times 10^{7}$ & $4.40 \times 10^{7}$ & -5.7 & - \\
& After 24 h & & $4.40 \times 10^{7}$ & 2.5 & $5.7 \times 10^{-11}$ \\
calcoaceticus $_{\text {ATCC23055 }}{ }^{\mathrm{T}}$ & & & & & \\
& After 1 h & $1.57 \times 10^{7}$ & $2.44 \times 10^{7}$ & 20.5 & $8.4 \times 10^{-10}$ \\
& From 8-24 h & $3.11 \times 10^{7}$ & $6.58 \times 10^{7}$ & -4.7 & - \\
& 24 h & & $6.58 \times 10^{7}$ & 2.2 & $3.3 \times 10^{-11}$ \\
\hline
\end{tabular}

Note: - means negative uptake and should be interpreted as phosphate release. 
$3.5 \%$ alginate beads, without bacteria, also showed phosphate adsorption of $1.5 \times 10^{-3} \mathrm{mg} \mathrm{P} / 1$ per mg of alginate (Figs 3 and 4). Comparing the phosphate uptake abilities of A. johnsonii and $A$. calcoaceticus after $1 \mathrm{~h}\left(5.9 \times 10^{-10}\right.$ and $\left.8.4 \times 10^{-10} \mathrm{mg} / \mathrm{cell}\right)$ and after $24 \mathrm{~h}$ of incubation $\left(5.7 \times 10^{-11}\right.$ and $3.3 \times 10^{-11} \mathrm{mg} / \mathrm{cell}$ ), no remarkable difference was found (Table 5). However, both strains showed a remarkable difference in their phosphate uptake ability after $1 \mathrm{~h}$ compared to $24 \mathrm{~h}$ after incubation (i.e. $5.9 \times 10^{-10}$ compared to $5.7 \times 10^{-10} \mathrm{mg} / \mathrm{cell}$, and $8.4 \times 10^{-10}$ compared to $3.3 \times 10^{-11} \mathrm{mg} / \mathrm{cell}$ ). The largest quantities of phosphate were removed within the first hour, irrespective of the species under consideration. The results in Figs 3 and 4 also indicated that phosphate was released slowly between $2 \mathrm{~h}$ and $8 \mathrm{~h}$, and removed again after $24 \mathrm{~h}$. Excess removal of phosphate has been reported to occur mainly under aerobic conditions, while phosphate uptake and release processes are reversible (Ohkate et al., 1985; Marais et al., 1983). In this study phosphate was released between 2 - $8 \mathrm{~h}$ under aerobic conditions. Release of phosphate in A. calcoaceticus under aerobic conditions after the cessation of growth has been reported by Ohkate et al. (1985). Hopson and Sack (1973) also reported aerobic phosphate release after the cessation of growth in Escherischia coli. Osborn and Nicholls (1978) have found that, when the aerobic period exceeded $4 \mathrm{~h}$ in the AS processes, a slow release of phosphate occurred even during the aerobic phase. The latter could explain the results obtained in this study since the cells were under aerobic conditions and not actively growing.

\section{CONCLUSIONS}

This study indicated that immobilization did affect the viability of Acinetobacter cells. The effect of immobilization on the viability depended both on the alginate concentration, the strain, and the cell density. The leakage rate, however, depended only on the alginate concentration and the strain. Leaked cells were viable since they displayed a typical growth curve. The growth rate of immobilized $A$. calcoaceticus was twice that of free cells, while A. johnsonii immobilized and free cells showed similar growth rates. Immobilized $A$. calcoaceticus and $A$. johnsonii growing cells did not take up phosphate. However, those in the lag and stationary growth phases showed a high phosphate uptake ability. The largest quantities of phosphate were, however, removed within the first hour (lag phase) compared to 24 $\mathrm{h}$ after incubation.

Acknowledgements - The authors are indebted to ESKOM and the Water Research Commission of South Africa for funding of the research program.

\section{REFERENCES}

Bashan Y. (1986) Alginate beads as synthetic inoculant carriers for slow release of bacteria that affect plant growth. Appl. Environ. Microbiot. 51, 1089-1098.

Bosch M. (1992) Phosphorus uptake kinetics of Acinetobacter in activated sludge mixed liquor, MSc Thesis, University of Pretoria.

Bosch M. and Cloete T. E. (1993) The identification and classification of Acinetobacter strains exhibiting variations in phosphate accumulation by SDS-Page and numerical analysis. Curr. Microbiol. 27, 169-175.

Brodisch K. E. U. and Joyner S. J. (1982) The role of organisms other than Acinetobacter in biological phosphate removal in activated sludge processes. In Proceeding of a post conference seminar on phosphate removal in biological treatment processes, Council for Scientific and Industrial Research, Pretoria, South Africa.

Dhulster P., Barbotin J. and Thomas D. (1984) Culture and bioconversion use of a plasmid-harbouring strain of immobilized E. coli. Appl. Microbiol. Biotechnol. 20, 87-93.

Doran P. M. and Bailey J. E. (1986) Effects of immobilization on growth, fermentation properties, and macromolecular composition of Saccharomyces cerevisiae attached to gelatin. Biotechnol. Bioengng. 28, 73-87.

Gersberg R. M. and Allen D. W. (1984) Phosphorus uptake by Klebsiella pneumoniae and Acinetobacter calcoaceticus. In Proceedings of I A WPRC Conference on Enhanced Biological Phosphorus Removal from Waste Water, Paris, France, pp. 146-151.

Harold F. M. (1963) Accumulation of inorganic polyphosphate in Aerobacter aerogenes - relationship to growth and nucleic acid synthesis. J. Bad. 86, 216-221.

Hopson N. E. and Sack W. A. (1973) Cellular phosphorus changes under low-carbon stress. J. Wat. Pollut. Control Fed. 45, 8596.

Lawson E. N. and Tonhazy N. E. (1980) Changes in morphology and phosphate uptake patterns of Acinetobacter calcoaceticus strains. Water SA. 6, 105-112.

Marais G. V. R,, Loewenthal R. E. and Siebritz I. P. (1983) Observations supporting phosphate removal by biological excess uptake - a review. Wat. Sci. Tech. 15, 15-41.

Mattiasson B. and Hahn-Hagerdal B. (1982) Microenvironmental effects on metabolic behaviour of immobilized cells. Eur. J. Appl. Microbiol. Biolechnol. 16, 52-55.

Navarro J. M. and Durand G. (1977) Modification of yeast metabolism by immobilization onto porous glass. Eur. J. Appl. Microbiol. Biolechnol. 4, 243-254.

Ohtake H., Takahashi K., Tsuzuki Y. and Toda K. (1985) Uptake and release of phosphate by a pure culture of Acinetobacter calcoaceticus. Wat. Res. 19, 1587-1594.

Osborn D. W. and Nicholls H. A. (1978) Optimisation of the activated sludge process for the biological removal of phosphorus. Pro. Wat. Technol. 10, 261-277.

Poncelet D., Lencki R., Beaulieu C, Halle J. P., Neufeld R. J. and Fournier A. (1992) Production of alginate beads by 
emulsification/internal gelation - Methodology. Appl. Microbiol. Biolechnol. 38, 39-45.

Shinmyo A., Kimura H. and Okada H. (1982) Physiology of $\alpha$-amylase production by immobilized Bacillus amyloliquefaciens. Eur. J. Appl. Microbiol. Biotechnol. 14, 7-12.

Stephenson T. (1987) Acinetobacter: its role in biological phosphate removal. In Advances in Water Pollution Control, Biological Phosphate Removal from Wastewaters (Edited by R. Ramadori), IAWPRC, pp. 313-316.

Takata I., Tosa T. and Chibata I. (1977) Screening of matrix suitable for immobilization of microbial cells. J. Solid-Ph. Biochem. $2,225-236$.

Toerien D. F., Gerber A., Lotter L. H. and Cloete T. E. (1990) Enhanced biological phosphorus removal in activated sludge systems. In Advances in Microbial Ecology 11, 173-230.

Vijayalakshmi M., Marcipar A., Segard E. and Broun G. B. (1979) Matrix-bound transition metal for continuous fermentation tower packing. Ann. N. Y. Acad. Sci. 326, 248-254. 